\title{
Research Report Optimized Production of High-Titer Recombinant Adeno-Associated Virus in Roller Bottles
}

\author{
Y.-L. Liu, K. Wagner, \\ N. Robinson, D. Sabatino, \\ P. Margaritis, W. Xiao, and \\ R.W. Herzog \\ The Children's Hospital of \\ Philadelphia, Philadelphia, PA, \\ USA
}

\begin{abstract}
Adeno-associated viral (AAV) vectors are used for in vivo gene transfer in a number of preclinical models of genetic diseases (including large-animal models) and are currently being tested in clinical trials for treatment of hemophilia $B$ and cystic fibrosis. Protocols for production of AAV vectors in a helper virus-free system are available and are based on transient transfection of HEK-293 cells with multiple plasmids. Scale-up of vector production has been labor intensive and inefficient because of a lack of larger culture vessels suitable for growth of adherent cells, large-scale transfection, and vector production. Here we report efficient production of AAV vector in roller bottles, which represents a 10-fold scale-up from the conventional flask or plate method. Optimized production yielded greater than $10^{13}$ vector genomes per bottle and was as cost effective as published protocols using plates. Successful vector production by this method was dependent on optimization of transfection by calcium phosphate precipitation, of monitoring of cell growth (by measurement of glucose consumption), of cell culture conditions, and $\mathrm{CO}_{2}$ /air exchange with the culture vessel.
\end{abstract}

\section{INTRODUCTION}

Adeno-associated viral (AAV) vectors are gene transfer vehicles derived from a replication-deficient member of the parvovirus family with a singlestranded 4.7-kb DNA genome. These vectors are attractive for in vivo gene transfer to a number of target cells including hepatocytes, muscle fibers, neurons, photoreceptors, and airway epithelial cells $(1,5,21,26)$. AAV vectors do not contain viral coding sequences, can efficiently transduce non-dividing target cells, resulting in long-term transgene expression, and have an excellent toxicity and safety profile $(2,11,20,22)$. Phase I clinical trials in patients with hemophilia B (HB) or with cystic fibrosis (CF) have been initiated using muscle or liver (HB) or airway epithelial cells (CF) as targets for transfer of an AAV vector encoding a coagulation factor IX (HB) or CFTR (CF) gene $(3,12,18,23)$. Many of the preclinical studies for these trials have been carried out in large-animal models, namely hemophilic dogs and nonhuman primates $(6,11,17,20,24)$. Experiments in these animals may represent a greater than 2 log scale-up from murine models (10-20-kg dogs vs. a 25-g mouse), which illustrates the need for efficient scale-up of vector production even in a setting of preclinical experimentation (10). AAV vectors can be produced by triple transfection of human embryonic kidney (HEK-293) cells without the need for a helper virus $(7,15,27)$. Advantages of this system include the fact that vectors with different expression cassettes or of different AAV serotypes can be rapidly produced simply by exchanging the vector plasmid or the AAV helper plasmid. In the latter case, we utilize plasmids that retain the AAV-2 rep gene but contain cap genes of the alternate serotype to be produced $(19,25)$. The third plasmid includes adenovirus helper genes, thereby bypassing the need for a helper virus. However, scaleup of this technique has been labor intensive and cumbersome because of unsuccessful vector production in culture vessels that are larger than standard tissue culture plates or flasks. Here we demonstrate successful production of high-titer AAV vector in roller bottles, which represents a 10-fold scale-up from conventional methods.

\section{MATERIALS AND METHODS}

\section{Plasmids}

The three plasmids our laboratory currently uses for AAV vector production are a vector plasmid encoding an expression cassette for the transgene flanked by AAV-2 inverted terminal repeats, a second plasmid encoding AAV replication and capsid functions (p5E18 for production of AAV-2), and a third plasmid containing adenoviral helper genes E2A, E4, and VA (4). All $\mathrm{AAV}$ helper plasmids have been engineered to reduce rep gene expression (resulting in increased vector production) and to reduce the potential for generation of pseudo-wild-type AAV in vector preparations $(4,14,16,25)$. 
Table 1. Comparison of Vector Production by Triple Transfection in 150-mm Tissue Culture Plates and Roller Bottles

\begin{tabular}{|c|c|c|c|c|}
\hline & Vector Yield (vg) & $\begin{array}{c}\% \text { Transfected } \\
\text { Cells }(\bar{x} \pm S D)\end{array}$ & Cell Count & vg/Transfected Cell \\
\hline 150-mm Plates & $\begin{array}{l}(5.6 \pm 3.4) \times 10^{12} \\
(\text { per } 10 \text { plates })\end{array}$ & $43 \pm 12$ & $\begin{array}{l}\text { approximately } 8.5 \times 10^{8} \\
\text { (per } 10 \text { plates) }\end{array}$ & $1.5 \times 10^{4}$ \\
\hline Roller Bottle & $\begin{array}{l}(1.9 \pm 1) \times 10^{12} \\
(\text { per bottle })\end{array}$ & $26 \pm 4$ & $\begin{array}{l}\text { approximately } 4 \times 10^{8} \\
\text { (per bottle) }\end{array}$ & $1.8 \times 10^{4}$ \\
\hline
\end{tabular}

\section{Plasmid Production}

Scale-up of triple transfection requires large amounts of plasmid DNA, which we produce by using the GIGA plasmid DNA purification kit from Qiagen (Valencia, CA, USA) for vector and AAV helper plasmids. Since the adenoviral helper plasmid is identical for all vector production runs, we have been producing large stocks of this DNA using the Ultrapure-100 column from Qiagen loaded with lysate from 40 L E. coli (DH5 $\alpha$ strain) culture, yielding $90 \pm 38 \mathrm{mg}$ plasmid DNA/ preparation ( $n=4$ preparations).

\section{Vector Production}

Viral vectors were produced by triple transfection in a helper virus-free system using HEK-293 cells (15). The optimized transfection protocol is documented in the Results section. Tissue culture media DMEM (with high glucose and L-glutamine) and IMDM (containing $\mathrm{NaHCO}_{3}$ and $25 \mathrm{mM}$ HEPES) were obtained from Invitrogen (Carlsbad, CA, USA).

\section{Vector Purification}

Cells were harvested $84-96$ h posttransfection, pelleted by a $30-\mathrm{min}$ centrifugation step at $1000 \times g$ at $4^{\circ} \mathrm{C}$, resuspended in a small volume of $10 \mathrm{mM}$ Tris buffer, $\mathrm{pH} 8.0$, and frozen at $-80^{\circ} \mathrm{C}$. Cells were lysed by ultra-sonication, and vector was purified by repeated $\mathrm{CsCl}$ density gradient centrifugation and filter-sterilized as described previously $(8,11)$. Vector yields were determined by quantitative slot blot hybridization as described $(8,13)$.

\section{RESULTS AND DISCUSSION}

\section{Optimization of Transfection}

The transfection step is most critical for achieving high-titer vector yield. In our optimized protocol, the three plasmids are mixed in an approximately equal molar ratio in $250 \mathrm{mM} \mathrm{CaCl}_{2}$ solution $(1 \mathrm{mg}$ total plasmid DNA in 25 $\mathrm{mL} \mathrm{CaCl}{ }_{2}$ solution, sufficient for transfection of 20150 -mm plates; $\mathrm{CaCl}_{2}$ solution is prepared from filter-sterilized $1 \mathrm{M}$ stock stored at $-20^{\circ} \mathrm{C}$ ). HEPES buffer $(0.3 \mathrm{M} \mathrm{NaCl}, 40 \mathrm{mM}$ HEPES, $\mathrm{pH} 7.05$, autoclaved and stored at room temperature) is mixed with $70 \mathrm{mM}$ $\mathrm{Na}_{2} \mathrm{HPO}_{4}$ (autoclaved and stored at room temperature) at a ratio of 50:1. Preparing and storing separate phosphate and HEPES solutions increased transfection efficiency by 3 - to 12 -fold compared with preparing a buffer containing both components and yielded much improved stability of the $\mathrm{pH}$ during storage (both solutions can be stored for at least three months without a measurable loss of transfection efficiency; data not shown). HEPES/phosphate buffer $(25 \mathrm{~mL})$ is added to a 200 $\mathrm{mL}$ conical tube, which is placed on a vortex, and $25 \mathrm{~mL} \mathrm{DNA} / \mathrm{CaCl}_{2}$ solution are added drop-wise while constantly vortex mixing. Subsequently, a DNA precipitate is allowed to form by incubation at room temperature for about $25 \mathrm{~min}$. For scale-up, such batches of transfection cocktail are produced in approximately 5-min intervals for transfection of plates (or shorter intervals for roller bottle method; see below). The $\mathrm{pH}$ of the HEPES buffer is critical for efficient transfection. We tested buffer solutions differing by 0.05
$\mathrm{pH}$ units and obtained optimal results with pH 7.05 (9). Transfection efficiency dropped by greater than $1 \log$ for solutions with $\mathrm{pH}$ greater than 7.1. As $\mathrm{pH}$ meter instruments and standards may give slightly variable results, we suggest that each laboratory perform similar testing to determine an optimal $\mathrm{pH}$ value.

\section{Vector Production in Plates}

Using this optimized transfection procedure, AAV vectors were produced by transfection of HEK-293 cells grown to $80 \%-90 \%$ confluence in $150-\mathrm{mm}$ plates. Before transfection, media (20 $\mathrm{mL} /$ plate) was changed from DMEM/$10 \%$ FBS/antibiotics to IMDM/ $2 \%$ FBS/antibiotics. The DNA precipitate was briefly vortex mixed and then added to conditioned media $(2.5 \mathrm{~mL}$ containing $50 \mu \mathrm{g}$ plasmid DNA/plate). Plates were returned to the incubator $\left(37^{\circ} \mathrm{C}, 5 \% \mathrm{CO}_{2}\right.$ in air), and media were changed to DMEM/2\% FBS/antibiotics after 6-8 h. Cells were harvested 84-96 $\mathrm{h}$ post-transfection, processed as outlined in Materials and Methods, and vector purified by repeated $\mathrm{CsCl}$ gradient centrifugation as described previously (8). Using these methods, we were able to routinely produce $10^{11}-10^{13}$ vector genomes (vg) per 10 plates (as determined by quantitative slot blot hybridization), depending on the construct and serotype (Table 1 and data not shown). In a direct comparison, our calcium phosphate reagents gave a 10 -fold higher vector yield than what was obtained using Polyfect ${ }^{\circledR}$ (Qiagen), a commercially available transfection reagent suitable for use with HEK-293 cells (data not shown). 


\section{Vector Production in Cell Factories}

As manipulation of individual plates represents a time-consuming and laborintensive process, it is not suitable for scale-up of vector production. Therefore, we tested alternative tissue culture vessels with higher capacity for cell growth. Cell factories (Nalge Nunc International, Rochester, NY, USA) with a surface area of $6000 \mathrm{~cm}^{2}$ (10-stack, approximately equivalent to 40.5 of 150 $\mathrm{mm}$ plates by area) were tested first. Cells were grown in cell factories until $80 \%-90 \%$ confluent (about 3 days of growth after inoculation with $1-2 \times 10^{8}$ cells) and then triple-transfected to generate an AAV2-GFP vector. An equivalent number of $150-\mathrm{mm}$ plates were transfected in parallel. In two separate experiments, vector yield was 5- to 20fold lower from the cell factory than with the plate method (data not shown).

\section{Vector Production in Roller Bottles}

Roller bottles (expanded surface roller bottles with easy-grip caps; Corning, Acton, MA, USA) with a surface area of $1700 \mathrm{~cm}^{2}$ (approximately equivalent to 11.5 of $150-\mathrm{mm}$ plates by area) were subsequently tested as a culture container. Cells were seeded at equivalent ratio in $150-\mathrm{mm}$ plates or roller bottles $\left(5 \times 10^{6} /\right.$ plate and $5 \times$ $10^{7} /$ roller bottle). Using roller bottles, HEK-293 cells were grown in $200 \mathrm{~mL}$ DMEM/10\% FBS/antibiotics. Media changes to IMDM or DMEM medium were performed as described above for plates, using $200 \mathrm{~mL}$ media/bottle. Roller bottles were incubated in a water-jacketed $\mathrm{CO}_{2}$ (5\% in air) incubator containing a cell culture roller apparatus with a maximum capacity of 35 bottles. A total of three parallel preparations of 20 plates or two roller bottles were done. When cells in $150-\mathrm{mm}$ plates were $80 \%-90 \%$ confluent $(2-3$ days of growth), triple transfection was performed to generate an AAV2-GFP vector. Transfection cocktail was added to the media of each bottle at the amount of $25 \mathrm{~mL}$ calcium phosphate precipitate containing $0.5 \mathrm{mg}$ plasmid DNA (i.e., the equivalent amount of DNA added to 10 plates). Cells were counted and examined at harvest day (day 4 post-transfection) for GFP ex-

Table 2. Determination of Cell Seeding Number for Inoculation of Roller Bottle and Time Point of Transfection

\begin{tabular}{|lccc|}
\hline & $\begin{array}{c}\text { No. of Cells } \\
\text { Seeded/ } \\
\text { Plate or Bottle }\end{array}$ & $\begin{array}{c}\text { Glucose } \\
\text { Concentration } \\
\text { ( } \mathbf{m g} / \mathbf{d L})\end{array}$ & $\begin{array}{c}\text { Vector } \\
\text { Yield } \mathbf{( v g )}\end{array}$ \\
\hline 150-mm Plates & $5 \times 10^{6}$ & 135.8 & $\begin{array}{c}2.9 \times 10^{13} \\
\text { (per 10 plates) }\end{array}$ \\
Roller Bottle & $5 \times 10^{7}$ & 175.8 & $2.3 \times 10^{13}$ \\
& $6 \times 10^{7}$ & 163.2 & $2.2 \times 10^{13}$ \\
& $8 \times 10^{7}$ & 161.8 & $5.2 \times 10^{13}$ \\
& $1 \times 10^{8}$ & 146.3 & $2.7 \times 10^{13}$ \\
& $1.2 \times 10^{8}$ & 142.4 & $2.9 \times 10^{13}$ \\
Increasing numbers of cells were used to inoculate cultures in roller bottles in \\
parallel with inoculation of 10 150-mm plates (1:10 split). When cells in 150-mm \\
plates reached 80\%-90\% confluence, glucose concentrations in conditioned me- \\
dia were determined. At this time point, cells were triple-transfected to produce \\
an AAV2-GFP vector. Vector yields from each different preparation are shown (10 \\
plates or one bottle/preparation).
\end{tabular}

pression by either fluorescence microscopy (one preparation) or by FACS $^{\circledR}$ (BD Biosciences, San Jose, CA, USA) (two preparations). The percentage of green-fluorescent cells was used to estimate the transfection efficiency. As shown in Table 1, vector yield from roller bottles was on average 3 -fold lower than from plates. This was in part due to somewhat reduced transfection efficiency in the bottles and in part due to a 2-fold greater yield of cells from plates, while the number of viral particles produced per transfected cell was similar for both methods (Table 1). When 10-fold serial dilutions of AAV-GFP vector preparations were tested for transduction of HEK-293 cells in the presence of adenovirus, the ratio of total to infectious particles was 1:100-1:1000 for both production methods, as one would have expected for $\mathrm{AAV}$ vector purified by $\mathrm{CsCl}$ density centrifugation (data not shown).

\section{Optimization of Vector Production in Roller Bottles}

Cell counts suggested that cell growth in the roller bottles had reached only about $50 \%$ of the capacity of the bottles as determined by the available surface area. In subsequent experiments, we attempted to improve gas exchange between bottles and incubator by loosening bottle caps, which were secured with autoclave tape, an inex- pensive alternative to the use of vented caps. Furthermore, we evaluated the influence of the amount of cell inoculum per bottle on vector yield and determined glucose levels in conditioned media at the time of transfection as an indicator for cell growth (Table 2). In this series of parallel transfections, AAV-GFP vector yield from roller bottles was identical to the yield from plates and similar for a wide range of cell inocula (Table 2 and Figure 1B). Again, transfection was carried out once cells in plates were $80 \%-90 \%$ confluent. The data show that seeding of $5 \times 10^{7}$ cells/bottle (cells from one fully confluent $150-\mathrm{mm}$ plate, representing a 1:10 cell split on the basis of surface area) is sufficient to achieve adequate cell growth for production of high-titer AAV vector. With this modification for improved gas exchange, cell numbers at the time of harvest/bottle were similar to cell yield from 10 plates (data not shown). Glucose consumption over time in media of roller bottles following inoculation with $8 \times 10^{7}$ cells was similar to consumption in $150-\mathrm{mm}$ plates inoculated with $5 \times 10^{6}$ cells (Figure 1A), suggesting similar growth characteristics when adequate exchange of gases between the culture vessel and the incubator is established. This may not have been the case for the cell factory, which could explain the unsuccessful scale-up of vector production in that system. In follow-up experiments, we 
Table 3. Yield of AAV Vector Preparations Comparing Current Production in Roller Bottles with Historical Data from Conventional Method Using 150-mm Plates

\begin{tabular}{|ccccc|}
\hline Serotype & Promoter & Transgene & $\begin{array}{c}\text { Yield (vg)/10 } \\
\text { 150-mm plates }\end{array}$ & $\begin{array}{c}\text { Yield (vg)/ } \\
\text { Roller Bottle }\end{array}$ \\
\hline AAV-1 & CMV & Factor IX & $(6.9 \pm 6) \times 10^{11}$ & $(2.8 \pm 2.6) \times 10^{12}$ \\
AAV-2 & CMV & Factor IX & $(5.9 \pm 4) \times 10^{12}$ & $5.2 \times 10^{12}$ \\
AAV-2 & CMV & GFP & $(3 \pm 1) \times 10^{13}$ & $(2 \pm 1.2) \times 10^{13}$ \\
AAV-5 & CMV & Factor IX & not done & $(2.6 \pm 0.9) \times 10^{13}$ \\
Yields are per 10 plates or per bottle as titered by quantitative slot blot hybridiza- \\
tion. All vectors were purified by CsCl gradient centrifugation. Indicated are AAV \\
serotype, promoter, and transgene as present in the expression cassette encod- \\
ed by the vector. Yields are mean in vg \pm SD for 3-5 preparations except for \\
AAV2-CMV-F.IX produced in roller bottles (one preparation only). Factor IX is hu- \\
man factor IX. CMV, cytomegalovirus.
\end{tabular}

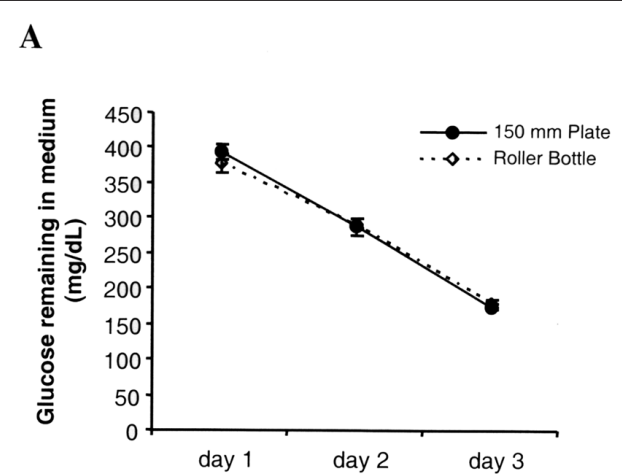

B

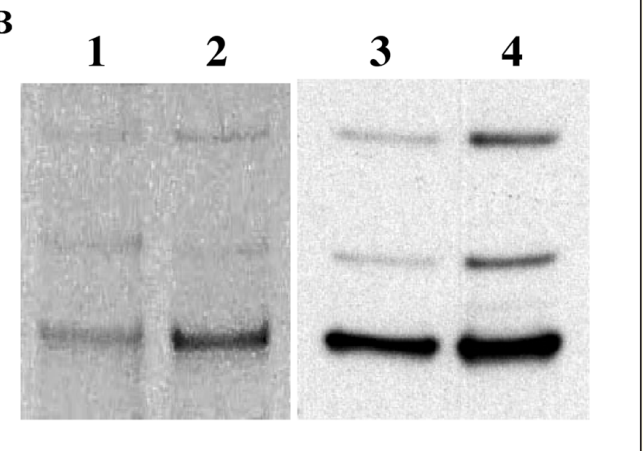

Figure 1. Vector production in roller bottles. Bottles were incubated in a water-jacketed reach-in $\mathrm{CO}_{2}$ incubator by Thermo Forma (Marietta, OH, USA) containing a cell culture roller apparatus (modular roller deck kit; Wheaton, Milluille, NJ, USA) with 35 slots. (A) Glucose reading from medium can be used as an index to monitor cell growth in roller bottles. Plates $(150-\mathrm{mm})$ were inoculated with $5 \times 10^{6}$ cells/plate $(n=5)$ and roller bottles with $8 \times 10^{7}$ cells each $(n=4)$. Culture medium was drawn daily and tested with a glucose meter (Accuchek ${ }^{\circledR}$ glucose meter; Roche Applied Science, Indianapolis, IN, USA). Results ( \pm SD) from 150-mm plates are shown in closed circles (solid line) and from roller bottles in open triangles (dotted line). (B) SDS-PAGE of purified AAV2-GFP vector (2 $\mu \mathrm{L}$ final vector preparation/well) for visualization of AAV2 VP1, VP2, and VP3 capsid proteins. Lanes 1 and 2, Coomassie Blue ${ }^{\circledR}$-stained gel. Lanes 3 and 4, Western blot incubated with anti-AAV2 capsid proteins (Maine Biotechnology Services; Portland, ME, USA). Lanes 1 and 3, vector produced in 150$\mathrm{mm}$ plates. Lanes 2 and 4, vector produced in roller bottles. found that glucose levels in $150-\mathrm{mm}$ plates tended to be slightly lower when cells reached $80 \%-90 \%$ confluence, as compared to media from cells grown in bottles for an identical length of time (Table 2). For the purpose of standardizing vector production runs, subsequent transfections in roller bottles have been carried out when the glucose concentration in conditioned media reached approximately $160 \mathrm{mg} / \mathrm{dL}$. The optimized protocol for vector production in roller bottles (Figure 2) allowed us to manufacture high-titer AAV vectors of different serotypes reproducibly (Table 3). Pseudotyped AAV-5 vectors typically gave a somewhat higher yield, and AAV-1 vectors gave a 2- to 5-fold lower yield for the same vector genome compared with the AAV-2 vector.

In summary, AAV vector can be produced at high titer by triple transfection of HEK-293 cells in roller bottles. Vector yields of $10^{12}$ to greater than $10^{13} \mathrm{vg} /$ bottle have been routinely obtained with this method, which allows convenient scale-up in the laboratory with greatly reduced labor, time, and risk of contamination that is associated with handling large amounts of individual flasks or plates. Costs for plastic ware, media, and plasmid DNA are identical for roller bottle production and conventional tissue culture plate methods, thus making this method attractive for academic laboratories and core facilities.

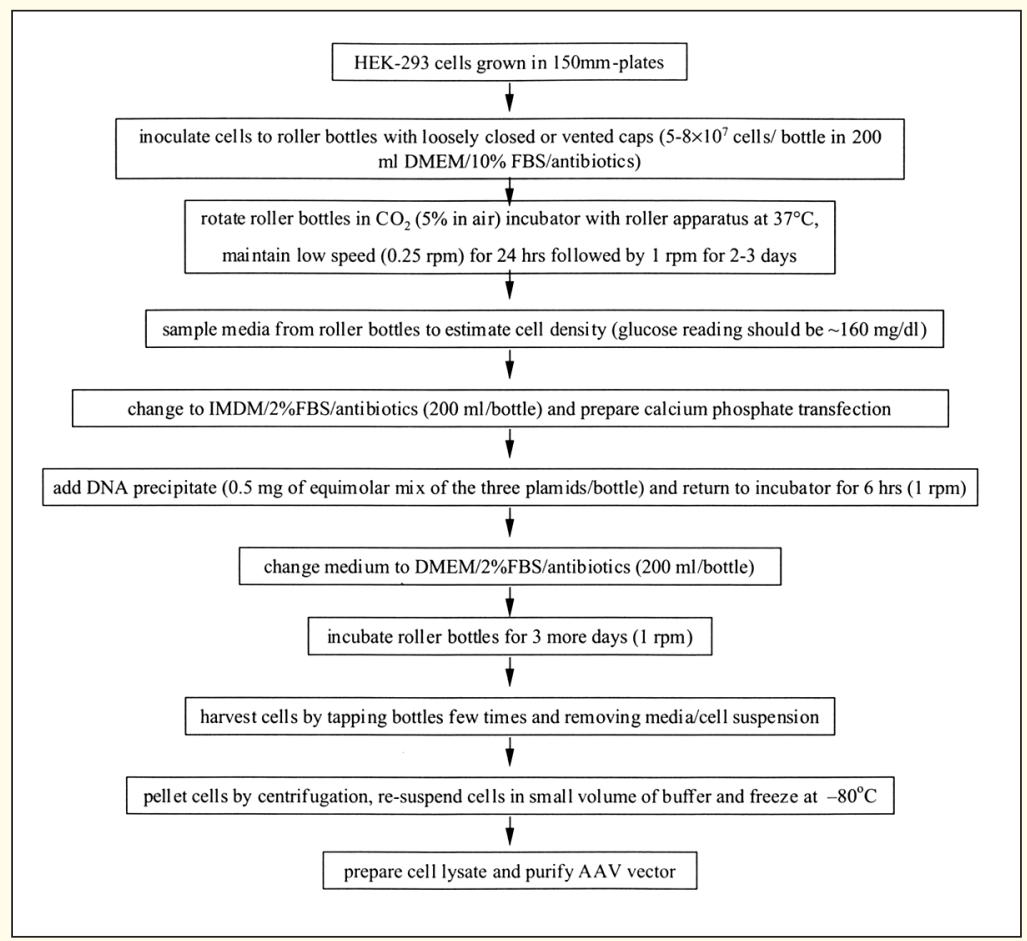

Figure 2. Diagram of vector production protocol in roller bottles. Cells were grown initially in tissue culture plates and then seeded in roller bottles. Transfection was done when glucose reading fell to the range of $160 \mathrm{mg} / \mathrm{dL}$. Cells were then cultured for an additional 84-96 $\mathrm{h}$ and were subsequently harvested. 


\section{ACKNOWLEDGMENTS}

This work was supported by The Children's Hospital of Philadelphia and National Institutes of Health grant no. U01HL66948 to R.W.H. R.W.H. is supported by a Career Development Award from the National Hemophilia Foundation. AAV-GFP vector plasmid was kindly provided by Avigen (Alameda, CA, USA).

\section{REFERENCES}

1.Acland, G.M., G.D. Aguirre, J. Ray, Q. Zhang, T.S. Aleman, A.V. Cideciyan, S.E. Pearce-Kelling, V. Anand, et al. 2001. Gene therapy restores vision in a canine model of childhood blindness. Nat. Genet. 28:92-95.

2.Afione, S.A., C.K. Conrad, W.G. Kearns, S. Chunduru, R. Adams, T.C. Reynolds, W.B. Guggino, G.R. Cutting, et al. 1996. In vivo model of adeno-associated virus vector persistence and rescue. J. Virol. 70:3235-3241.

3.Aitken, M.L., R.B. Moss, D.A. Waltz, M.E. Dovey, M.R. Tonelli, S.C. McNamara, R.L. Gibson, B.W. Ramsey, et al. 2001. A phase I study of aerosolized administration of tgAAVCF to cystic fibrosis subjects with mild lung disease. Hum. Gene Ther. 12:19071916.

4.Cao, L., Y. Liu, M.J. During, and W. Xiao. 2000. High-titer, wild-type free recombinant adeno-associated virus vector production using intron-containing helper plasmids. J. Virol. 74:11456-11463.

5.Carter, P.J. and R.J. Samulski. 2000. Adeno-associated viral vectors as gene delivery vehicles. Int. J. Mol. Med. 6:17-27.

6.Favre, D., N. Provost, V. Blouin, G. Blancho, Y. Cherel, A. Salvetti, and P. Moullier. 2001. Immediate and long-term safety of recombinant adeno-associated virus injection into the nonhuman primate muscle. Mol. Ther. 4:559-566.

7.Ferrari, F.K., X. Xiao, D. McCarty, and R.J. Samulski. 1997. New developments in the generation of Ad-free, high-titer rAAV gene therapy vectors. Nat. Med. 3:1295-1297.

8.Fisher, K.J., G.P. Gao, M.D. Weitzman, R. DeMatteo, J.F. Burda, and J.M. Wilson. 1996. Transduction with recombinant adenoassociated virus for gene therapy is limited by leading-strand synthesis. J. Virol. 70:520532.

9.Graham, F.L. and A.J. van der Eb. 1973. A new technique for the assay of infectivity of human adenovirus 5 DNA. Virology 52:456467.

10.Herzog, R.W. and J.N. Hagstrom. 2001. Gene therapy for hereditary hematological disorders. Am. J. Pharmacogenomics 1:137144.

11.Herzog, R.W., E.Y. Yang, L.B. Couto, J.N. Hagstrom, D. Elwell, P.A. Fields, M. Burton, D.A. Bellinger, et al. 1999. Long-term correction of canine hemophilia B by gene transfer of blood coagulation factor IX medi- ated by adeno-associated viral vector. Nat. Med. 5:56-63

12.Kay, M.A., C.S. Manno, M.V. Ragni, P.J. Larson, L.B. Couto, A. McClelland, B. Glader, A.J. Chew, et al. 2000. Evidence for gene transfer and expression of factor IX in haemophilia B patients treated with an AAV vector. Nat. Genet. 24:257-261.

13.Kessler, P.D., G.M. Podsakoff, X. Chen, S.A. McQuiston, P.C. Colosi, L.A. Matelis, G.J. Kurtzman, and B.J. Byrne. 1996. Gene delivery to skeletal muscle results in sustained expression and systemic delivery of a therapeutic protein. Proc. Natl. Acad. Sci. USA 93:14082-14087.

14.Li, J., R.J. Samulski, and X. Xiao. 1997. Role for highly regulated rep gene expression in adeno-associated virus vector production. J. Virol. 71:5236-5243.

15.Matsushita, T., S. Elliger, C. Elliger, G. Podsakoff, L. Villarreal, G.J. Kurtzman, Y. Iwaki, and P. Colosi. 1998. Adeno-associated virus vectors can be efficiently produced without helper virus. Gene Ther. 5:938-945.

16.Matsushita, T., S. Godwin, R. Surosky, and P. Colosi. 1999. Improvements in AAV vector production: elimination of pseudo-wild type AAV., p. 2a. In Proceedings of the 2nd Annual American Society of Gene Therapy, Washington, DC.

17.Mount, J.D., R.W. Herzog, D.M. Tillson, S.A. Goodman, N. Robinson, M.L. McCleland, D. Bellinger, T.C. Nichols, et al. 2002. Sustained phenotypic correction of hemophilia B dogs with a factor IX null mutation by liver-directed gene therapy. Blood 99:26702676.

18.Nakai, H., K. Ohashi, V.R. Arruda, A. McClelland, L.B. Couto, L. Meuse, T. Storm, M.D. Dake, et al. 2000. A proposed rAAVliver directed clinical trial for hemophilia B. Blood 96(Suppl):798a-799a.

19.Rabinowitz, J.E., F. Rolling, C. Li, H. Conrath, W. Xiao, X. Xiao, and R.J. Samulski. 2002. Cross-packaging of a single adeno-associated virus (AAV) type 2 vector genome into multiple AAV serotypes enables transduction with broad specificity. J. Virol. 76:791-801.

20.Snyder, R.O., C. Miao, L. Meuse, J. Tubb, B.A. Donahue, H.-F. Lin, D.W. Stafford, S. Patel, et al. 1999. Correction of hemophilia $\mathrm{B}$ in canine and murine models using recombinant adeno-associated viral vectors. Nat Med. 5:64-70.

21.Snyder, R.O., C.H. Miao, G.A. Patijn, S.K. Spratt, O. Danos, D. Nagy, A.M. Gown, B. Winther, et al. 1997. Persistent and therapeutic concentrations of human factor IX in mice after hepatic gene transfer of recombinant AAV vectors. Nat. Genet. 16:270-276.

22.Wagner, J.A., A.H. Messner, M.L. Moran, R. Daifuku, K. Kouyama, J.K. Desch, S. Manley, A.M. Norbash, et al. 1999. Safety and biological efficacy of an adeno-associated virus vector-cystic fibrosis transmembrane regulator (AAV-CFTR) in the cystic fibrosis maxillary sinus. Laryngoscope 109:266-274.

23.Wagner, J.A., T. Reynolds, M.L. Moran, R.B. Moss, J.J. Wine, T.R. Flotte, and P. Gardner. 1998. Efficient and persistent gene transfer of AAV-CFTR in maxillary sinus.
Lancet 351:1702-1703

24.Wang, L., T.C. Nichols, M.S. Read, D.A. Bellinger, and I.M. Verma. 2000. Sustained expression of therapeutic level of factor IX in hemophilia B dogs by AAV-mediated gene therapy in liver. Mol. Ther. 1:154-158.

25.Xiao, W., N. Chirmule, S.C. Berta, B. McCullough, G. Gao, and J.M. Wilson. 1999. Gene therapy vectors based on adeno-associated virus type 1. J. Virol. 73:3994-4003.

26.Xiao, X., J. Li, and R.J. Samulski. 1996. Efficient long-term gene transfer into muscle tissue of immunocompetent mice by adenoassociated virus vector. J. Virol. 70:80988108.

27.Xiao, X., J. Li, and R.J. Samulski. 1998. Production of high-titer recombinant adenoassociated virus vectors in the absence of helper adenovirus. J. Virol. 72:2224-2232.

Received 9 September 2002; accepted 31 October 2002.

\section{Address correspondence to:}

Dr. Roland W. Herzog

The Children's Hospital of Philadelphia

Abramson Research Center, Rm. 310

34th St. and Civic Center Blvd.

Philadelphia, PA 19104, USA

e-mail: rwherzog@mail.med.upenn.edu 